\title{
PERAN LACTOBACILLUS PADA MANAGEMEN INFEKSI ENDOGEN GENITALIA WANITA
}

\author{
Nadia Wirantari, Afif Nurul Hidayati \\ Departemen/Staf Medik Fungsional Ilmu Kesehatan Kulit dan Kelamin \\ FK Universitas Airlangga/RSU dr. Soetomo, Surabaya
}

\begin{abstract}
ABSTRAK
Infeksi endogen genitalia wanita merupakan infeksi yang disebabkan oleh perubahan keseimbangan bakteri endogen vagina, termasuk bacterial vaginosis $(B V)$ dan kandidiasis vulvovaginalis $(K V V)$. Keduanya menyebabkan angka kejadian dan rekurensi yang tinggi, dan regimen terapi standar menunjukkan efektivitas yang bervariasi. Akhir-akhir ini Lactobacillus sebagai probiotik sering digunakan untuk terapi dan pencegahan rekurensi pada $B V$ dan $K V V$. Lactobacillus merupakan flora normal dominan pada vagina, yang mampu menghasilkan asam laktat untuk menjaga pH normal, menghasilkan substansi antimikroba, menempel pada sel epitel vagina, dan menghambat pertumbuhan mikroba patogen. Penelitian menunjukkan efektivitas yang bervariasi dalam penggunaan Lactobacillus pada $B V$ dan $K V V$, baik dalam bentuk sediaan oral ataupun intravagina. Lactobacillus efektif digunakan dalam pencegahan rekurensi $B V$, dan sebaiknya digunakan sebagai kombinasi bersama terapi antibiotika standar. Penelitian in vitro mendukung efektivitas Lactobacillus dalam inhibisi Candida, namun dibutuhkan lebih banyak penelitian klinis yang baik untuk dapat menjelaskan lebih lanjut efektivitas dan keamanan Lactobacillus untuk terapi $K V V$.
\end{abstract}

Kata kunci: Lactobacillus, Bacterial Vaginosis, Kandidiasis Vulvovaginalis, rekurensi

\section{THE ROLE OF LACTOBACILLUS IN MANAGING ENDOGENOUS FEMALE GENITAL TRACT INFECTIONS}

\section{Korespondensi:}

Jl. Mayjen Prof.Dr.Moestopo No.6-8 Surabaya 60131,

Telepon: +62315501609

Email: nadiawirantari@yahoo.com

\begin{abstract}
Endogenous female genital tract infections are caused by a shift of vaginal endogen bacteria, including Bacterial Vaginosis (BV) and Vulvovaginal Candidiasis (VVC). Both have high prevalence and recurrence rates, and standard treatment regiment shows varied effectivity. Recently, Lactobacillus as probiotic is being used to treat and prevent recurrence in BV and VVC. As the dominant normal vaginal flora, Lactobacillus has the ability to produce lactic acid to maintain normal vaginal $\mathrm{pH}$, produce antimicrobial substances, and adhere to vaginal epithelial cells, thus inhibits the growth of pathogenic microbes. Studies show varied efficacy in treating and preventing reccurences of $B V$ and VVC with oral or intravaginal preparations of Lactobacillus. Lactobacillus is effective in preventing $B V$ recurrence, and is best to be used in combination with standard antibiotic therapy. In vitro studies have proven the efficacy of Lactobacillus in inhibiting the growth of Candida, but more good quality clinical studies are needed to further explain the effectivity and safety of Lactobacillus in the management of VVC.
\end{abstract}

Key words: Lactobacillus, Bacterial Vaginosis, Vulvovaginal Candidiasis, recurrence 


\section{PENDAHULUAN}

Infeksi endogen genitalia wanita merupakan infeksi pada vagina yang tidak menular secara seksual, namun disebabkan oleh perubahan keseimbangan bakteri endogen vagina, termasuk bacterial vaginosis (BV) dan kandidiasis vulvovaginalis (KVV). Keduanya menimbulkan angka kejadian tinggi, dengan prevalensi BV di Amerika Serikat $29 \%$ dan prevalensi KVV 70-75\% pada wanita usia reproduktif. ${ }^{1,2}$ Angka kesembuhan jangka panjang rendah, BV kambuh pada $40 \%$ wanita dalam 3 bulan setelah selesai terapi antibiotika dan pada $50 \%$ wanita setelah 6 bulan terapi. ${ }^{1} \quad$ Survei di Amerika Serikat menunjukkan $6,5 \%$ wanita mengalami $>1$ episode KVV dan $8 \%$ mengalami $>4$ episode KVV dalam setahun. ${ }^{2}$ Efektivitas penggunaan terapi standar untuk tatalaksana BV dan KVV bervariasi. Akhir-akhir ini, Lactobacillus dengan potensi probiotik sering digunakan sebagai sediaan intravagina ataupun oral untuk terapi dan pencegahan rekurensi BV dan $\mathrm{KVV}^{3}$ Sampai saat ini efektivitas dan keamanan Lactobacillus untuk terapi BV dan KVV masih dipertanyakan.

Angka kekambuhan yang tinggi pada infeksi endogen genitalia wanita disebabkan oleh kemungkinan resistensi antibiotika dan pembentukan mikroorganisme patogen di dalam biofilm bakteria. Sampai saat ini pilihan terapi untuk pencegahan rekurensi belum memuaskan. Infeksi endogen vagina rekurens dapat menyebabkan depresi dan gangguan dalam kehidupan profesional, personal, dan hubungan intim. ${ }^{4}$ Kekambuhan itu menyebabkan peningkatan pajanan terhadap antibiotika ataupun antijamur, dan munculnya galur yang resisten terhadap obat sehingga menimbulkan kebutuhan untuk alternatif terapi, misalnya produk probiotik. ${ }^{5}$

Lactobacillus adalah bakteri yang mendominasi vagina sehat, berperan dalam mempertahankan mikroflora normal dan keasaman normal vagina dengan produksi asam laktat. Lactobacillus juga menghasilkan bahan antimikroba dan berkompetisi dengan mikroorganisme lain untuk nutrisi intravagina, sehingga mencegah pertumbuhan berlebihan dari bakteri patogen dan organisme oportunistik. ${ }^{5}$ Terdapat banyak bukti bahwa pemberian Lactobacillus sebagai probiotik efektif untuk pencegahan dan atau terapi penyakit, terutama pada BV dan KVV, tetapi hasilhasil penelitian masih belum konsisten sehingga perlu dilakukan pengkajian tentang peran terapi Lactobacillus pada managemen infeksi endogen genitalia wanita.

Tinjauan pustaka ini bertujuan untuk memberikan pengetahuan tentang profil, mekanisme kerja, efektivitas, dan efek samping Lactobacillus sebagai probiotik, dalam penggunaannya untuk tatalaksana BV dan KVV. Penggunaan Lactobacillus dengan tepat diharapkan dapat menurunkan kekambuhan BV dan KVV dan meningkatkan kualitas hidup pasien.

\section{SISTEM PERTAHANAN VAGINA}

Vagina adalah lumen elastis yang terdiri atas 3 lapisan, yaitu dinding vagina berupa epitel skuamosa berlapis, lapisan tengah berupa otot polos, dan lapisan luar jaringan fibrosa. Vagina normal $\mathrm{pH}$ berkisar antara 3,5-4,5 yang mendukung kehidupan sejumlah mikroorganisme dan dipertahankan dengan produksi asam laktat oleh Lactobacillus sebagai flora normal yang mendominasi. ${ }^{6}$

Metabolisme glikogen yang merupakan sumber nutrisi utama mikroba vagina, diperantarai oleh hormon estrogen melalui reseptor estrogen pada epitel vagina. Aktivitas reseptor estrogen bergantung pada siklus hormon ovarium. Perubahan dinamis lingkungan vagina saat siklus menstruasi menyebabkan perubahan ekologi mikroflora vagina. ${ }^{6}$ Lapisan mukosa menyediakan nutrisi bagi mikroflora vagina dan berperan sebagai reseptor. Lactobacilli mengalami interaksi fisiokimia dengan epitel vagina, dan membentuk biofilm yang terdiri atas lapisan sel bakteria dan komponen sekretoris vagina. Hidrasi lapisan epitel menyebabkan penurunan permeabilitas lapisan mukosa terhadap organisme patogen. ${ }^{6}$

\section{MIKROFLORA NORMAL VAGINA}

Lactobacillus adalah bakteria fakultatif anaerob nonpatogen, berbentuk batang Gram positif yang berkolonisasi pada traktus genitalia, rongga mulut, dan lambung. Spesies Lactobacillus yang mendominasi traktus genitalia adalah $L$. acidophilus, L. iners, L. crispatus, L. gasseri dan $L$. jensenii. Regulasi flora normal pada vagina dilakukan melalui "bacterial interference" yaitu fenomena bakteri baik yang mendominasi lingkungan dan nutrisi sehingga bakteri patogen tidak berproliferasi. ${ }^{6}$

\section{INFEKSI ENDOGEN GENITALIA WANITA}

\section{Bacterial Vaginosis}

Untuk diagnosis BV dapat digunakan kriteria Amsel yaitu terdapat 3 dari 4 kriteria berikut: (1) discharge vagina tipis dan homogen; (2) $\mathrm{pH}$ vagina lebih tinggi dari 4,5; (3) bau amis pada cairan vagina setelah penambahan larutan 10\% kalium hidroksil (KOH) (whiff test); dan (4) ditemukan clue cells pada pemeriksaan mikroskopis. Pewarnaan Gram dari hapusan vagina merupakan pemeriksaan penunjang baku emas untuk diagnosis $\mathrm{BV} .^{7,8}$ Penyulit BV yaitu rekurensi, fasilitasi transmisi infeksi menular seksual lain, ruptur membran prematur pada kehamilan, kelahiran preterm, infeksi intra amniotik, dan endometritis pasca partus. ${ }^{5}$

Terapi yang direkomendasikan adalah metronidazol oral 2x500 mg selama 7 hari atau metronidazol gel 0,75\% $5 \mathrm{~g}$ intravagina sekali sehari selama 5 hari, atau krim klindamisin $2 \%, 5 \mathrm{~g}$ intravagina sebelum tidur selama 7 
hari. BV rekurens terjadi pada hampir 50\% wanita 6 bulan setelah terapi. Angka rekurensi yang tinggi terhadap pajanan antibiotika yang berulang dan munculnya galur resisten obat memberikan kebutuhan untuk alternatif terapi. $^{5,8}$

\section{Kandidiasis Vulvovaginalis (KVV)}

KVV merupakan infeksi kandida pada vagina dan vestibulum, dapat meluas ke luar labium minor, labium mayor, dan regio intercruris. ${ }^{9}$ Gejala klinis tersering adalah pruritus, dispareunia, disuria eksternal, dan discharge abnormal. Pada pemeriksaan klinis didapatkan edema vulva, fisura, ekskoriasi, atau fluor albus putih kental seperti susu pecah, $\mathrm{pH}<4,5$. Serviks tidak terinfeksi. ${ }^{9}$ Pemeriksaan mikroskopis berupa sediaan basil dengan pewarnaan laturan $\mathrm{KOH} 10 \%$, pewarnaan atau pemeriksaan basah yang menunjukkan budding yeast, blastospora, atau pseudohifa dapat memastikan diagnosis. Komplikasi yang dapat terjadi adalah KVV rekurens, yaitu $\geq 4$ episode KVV dalam setahun, dan KVV berat berupa eritema dan edema vulva yang berat, ekskoriasi dan fisura. ${ }^{9}$

Terapi rekomendasi KVV adalah antijamur topikal durasi cepat, misalnya klotrimazole $1 \%$ krim $5 \mathrm{~g}$ intravagina selama $7-14$ hari, klotrimazol $2 \%$ krim $5 \mathrm{~g}$ intravagina selama 3 hari, mikonazol $2 \%$ krim $5 \mathrm{~g}$ intravagina selama 7 hari, mikonazol 200mg vaginal suppository selama 3 hari. ${ }^{8}$ Pada KVV rekurens, terapi antijamur topikal dapat diberikan dalam jangka waktu lebih lama yaitu 7-14 hari. Namun 30-50\% wanita akan mengalami kekambuhan setelah terapi maintenance dihentikan. ${ }^{8}$

\section{PROBIOTIK (Lactobacillus)}

Lactobacillus merupakan flora intestinal dan urogenital nonpatogen, dan telah digunakan sebagai probiotik untuk infeksi traktus genital dan intestinal dengan berbagai derajat keberhasilan. Probiotik merupakan mikroorganisme hidup yang dapat memberikan keuntungan kesehatan pada pejamu apabila diberikan dalam jumlah yang cukup. Efek probiotik tergantung pada jumlah bakteri dalam produk sehingga kurangnya bakteri probiotik yang viabel akan menyebabkan berkurangnya efek probiotik. ${ }^{3}$

Kebanyakan probiotik telah disetujui oleh Food and Drug Andministration (FDA) sebagai Generally Regarded as Safe (GRAS). Pada seorang yang imunokompromais, bakteri probiotik termasuk Lactobacillus dapat translokasi karena defek barier usus, sehingga dapat menyebabkan bakteremia, septisemia, dan kegagalan organ multipel. Namun translokasi sangat sulit terjadi pada orang sehat, dan apabila terjadi, efeknya tidak membahayakan. ${ }^{10}$ Secara keseluruhan, jumlah kasus infeksi terkait Lactobacillus sangat sedikit dibandingkan dengan keuntungan dan penggunaannya yang luas. ${ }^{11}$ Produk probiotik yang mengandung Lactobacillus dianggap tidak berbahaya, dan tidak ada laporan infeksi yang disebabkan oleh probiotik genital. ${ }^{3}$ Tidak didapatkan kontra indikasi terhadap penggunaan Lactobacillus. ${ }^{8,9}$

\section{EVIDENCE-BASED PENGGUNAAN PROBIOTIK (LACTOBACILLUS) PADA INFEKSI ENDOGEN GENITALIA WANITA}

\section{Lactobacillus pada Bacterial Vaginosis}

Berdasarkan bukti bahwa penurunan Lactobacillus vagina menyebabkan perkembangan $\mathrm{BV}$, beberapa penelitian telah mengevaluasi efektivitas penggunaan Lactobacillus untuk terapi dan pencegahan rekurensi BV. Penelitian tersamar tunggal probiotik intravagina (L. rhamnosus GR1 dan L. fermentum RC-14) dibandingkan dengan gel metronidazol untuk terapi BV menunjukkan angka kesembuhan pada kelompok Lactobacillus 65\% dibandingkan dengan 33\% pada kelompok metronidazol setelah 30 hari $(\mathrm{P}=0,056) .{ }^{12}$ Penelitian tersamar ganda dengan kontrol plasebo dilakukan Mastromarino menggunakan produk kombinasi tiga spesies lactobacilli (L.brevis CD2, L.salivarius FV2, dan L.plantarum FV9) pada wanita dengan BV. Pada kelompok yang menggunakan lactobacilli didapatkan angka kesembuhan 50\% dibandingkan dengan $6 \%$ pada kelompok plasebo $(\mathrm{P}=0,017) .{ }^{13}$ Penelitian prospektif, tersamar ganda, acak, dengan kontrol plasebo, yang dilakukan oleh Ya dkk. mengevaluasi efektivitas probiotik intravagina (L. rhamnosus, L. acidophilus, dan Streptococcus thermophilus) sebagai profilaksis BV pada wanita sehat dengan riwayat BV rekurens, dibandingkan dengan kapsul plasebo intravagina selama 7 hari, kemudian berhenti selama 7 hari dan diberikan lagi 7 hari berikutnya. Profilaksis probiotik menghasilkan angka kekambuhan lebih rendah untuk BV $(15,8 \%)$ dibandingkan dengan plasebo $(45,0 \%)$ setelah 11 bulan evaluasi, dinilai dari kriteria Amsel $(\mathrm{P}<0,001){ }^{14}$

Beberapa penelitian yang mengevaluasi penggunaan kombinasi terapi antibiotika dan Lactobacillus untuk BV menunjukkan peningkatan angka kesembuhan BV secara konsisten. Petricevic mengevaluasi terapi klindamisin yang diikuti dengan probiotik L. casei rhamnosus (Lcr35) intravagina selama 7 hari, dibandingkan dengan kelompok kontrol yang tidak mendapat Lcr35. Setelah 4 minggu angka kesembuhan pada kelompok probiotik adalah $83 \%$, sedangkan kelompok plasebo $35 \%(\mathrm{P}<0,001) .{ }^{15}$ Martinez juga mengkonfirmasi bahwa pemberian L.rhamnosus GR1 dan $L$. reuteri $\mathrm{RC}-14$ selama 4 minggu setelah terapi standar memberikan angka kesembuhan yang lebih tinggi secara bermakna dibandingkan dengan antibiotika saja $(87,5 \%$ vs $50 \%, \quad \mathrm{P}=0,001){ }^{16}$ Marcone menunjukkan bahwa pemberian probiotik intravagina (L. rhamnosus) selama 2 bulan setelah terapi BV standar menghasilkan rekurensi yang lebih rendah. Pada evaluasi hari ke-90, angka kesembuhan sebesar $88 \%$ pada kelompok probiotik dibandingkan dengan $71 \%$ pada kelompok kontrol 
$(\mathrm{P}=0,05) .{ }^{17}$ Pada penelitian kedua, subjek penelitian menerima kapsul probiotik intravagina (L. rhamnosus) seminggu sekali sebagai terapi selama 6 bulan. Evaluasi pada bulan ke-6 dan bulan ke-12 menunjukkan prevalensi keseimbangan ekosistem vagina lebih tinggi pada kelompok probiotik dibandingkan dengan kelompok yang diterapi metronidazol saja (bulan ke-6: $96 \%$ vs $74 \%, \mathrm{P}<0,05$, bulan ke-12: $91 \%$ dan $69 \%, \mathrm{P}=0,40) .{ }^{18}$ Larsson dkk. melakukan penelitian dengan terapi berulang $L$. gasseri dan $L$. rhamnosus selama 3 siklus menstruasi, dibandingkan dengan plasebo, setelah terapi BV standar dengan krim klindamisin intravagina 2\%. Angka kesembuhan dievaluasi dengan skor Hay/Ison, menunjukkan bahwa 6 bulan setelah terapi, angka kekambuhan berkurang secara bermakna pada kelompok probiotik (65\% vs 46,2\%, $\mathrm{P}=0,042){ }^{19}$

Penggunaan Lactobacillus secara oral ataupun intravagina telah terbukti efektif dalam tatalaksana BV. Penggunaan Lactobacillus secara oral memiliki kemampuan untuk Lactobacillus bermigrasi dari usus ke vagina melalui kulit perineum dan vulva, namun penggunaan intravagina menguntungkan dalam efisiensi dosis, frekuensi penggunaan, dan tidak terganggu oleh penyerapan gastrointestinal. ${ }^{4}$ Kombinasi terapi antibiotika standar dan suplementasi probiotik Lactobacillus meningkatkan angka kesembuhan BV secara konsisten dan menurunkan angka rekurensi $\mathrm{BV}$, tanpa efek samping yang bermakna. Data tidak mendukung penggunaan Lactobacillus untuk menggantikan antibiotika sebagai terapi BV. ${ }^{4,6}$

\section{Lactobacillus pada Kandidiasis Vulvovaginalis}

Terdapat beberapa penelitian klinis yang dilakukan untuk mengetahui efektivitas sediaan oral maupun intravagina Lactobacillus pada wanita dengan KVV. Reid dkk. memberikan probiotik oral (L. rhamnosus GR-11 dan L. fermentum RC-14) dua kali sehari selama 14 hari kepada 10 wanita, 9 wanita di antaranya menderita KVV rekurens. Seminggu setelah terapi, Lactobacillus mendominasi vagina semua subjek penelitian dan tidak didapatkan kekambuhan KVV selama penelitian dan evaluasi. ${ }^{20}$ Sebuah uji klinis acak tersamar ganda, oleh Martinez dkk. mengevaluasi efektivitas pemberian flukonazol oral 150 $\mathrm{mg}$ dosis tunggal disertai probiotik per oral (L. rhamnosus GR-1 dan L. reuteri RC-14) diminum sekali sehari selama 28 hari dimulai bersamaan dengan penggunaan flukonazol, dibandingkan dengan terapi flukonazol oral dan kapsul plasebo pada populasi wanita dengan KVV. Angka kesembuhan berdasarkan kultur sebesar $89,7 \%$ pada kelompok yang diberi probiotik, dan $61,5 \%$ pada kelompok kontrol $(\mathrm{P}=0,014) .^{21}$ Kovachef melakukan penelitian pada wanita dengan KVV untuk mengevaluasi efektivitas terapi azol standar, yaitu flukonazol $150 \mathrm{mg}$ per oral dan fentikonazol $600 \mathrm{mg}$ dosis tunggal intravagina, dibandingkan dengan terapi azol dan kombinasi dengan 10 aplikasi probiotik intravaginal (L. acidophilus, L. rhamnosus, Streptococcus thermophilus dan $L$. delbrueckii) yang dimulai pada hari ke-5 setelah terapi azol. Persistensi gejala klinis pada kelompok azol adalah $79,7 \%$, dibandingkan dengan $31,1 \%$ pada kelompok kombinasi azol dan probiotik. $^{22}$ Murina dkk. mengevaluasi efektivitas tablet vagina lepas lambat yang mengandung L. fermentum LF10 dan L. acidophilus LA02 pada pasien KVV setelah pemberian flukonazol oral $200 \mathrm{mg}$ selama 3 hari, dan mendapatkan 72,4\% pasien bebas rekurensi pada evaluasi bulan ke-10. ${ }^{23}$

Beberapa penelitian in vitro dan penelitian klinis telah menunjukkan efektivitas beberapa strain lactobacilli terhadap $C$. albicans dan $C$. glabrata. Namun banyak penelitian klinis yang ada menggunakan jumlah sampel yang sedikit, tidak membandingkan dengan kontrol, atau tidak memastikan riwayat KVV rekurens pada sampel penelitian. ${ }^{11}$ Jenis Lactobacillus yang berbeda menunjukkan sifat dan efek terhadap Candida yang berbeda, sehingga hasil dari penelitian terhadap sebuah galur Lactobacillus seharusnya tidak diekstrapolasikan ke galur lain. L. acidophilus, L. rhamnosus GR-1 dan L. fermentum $R C-14$ dapat dipertimbangkan sebagai bahan pencegahan empiris potensial pada wanita dengan KVV rekurens, karena efek sampingnya yang juga sangat jarang. Dibutuhkan lebih banyak penelitian acak, bersamar ganda, dengan kontrol plasebo, dengan ukuran sampel yang lebih banyak agar dapat menjelaskan lebih lanjut efektivitas dan keamanan Lactobacillus pada terapi KVV. ${ }^{11}$

\section{SIMPULAN}

Lactobacillus efektif digunakan dalam pencegahan rekurensi BV, dan sebaiknya digunakan dengan kombinasi bersama terapi antibiotika standar. Penelitian in vitro mendukung efektivitas Lactobacillus dalam inhibisi Candida, namun dibutuhkan lebih banyak penelitian klinis yang baik untuk dapat menjelaskan lebih lanjut efektivitas dan keamanan Lactobacillus sebagai terapi KVV.

\section{DAFTAR PUSTAKA}

1. Allsworth JE, Peipert JF. Prevalence of bacterial vaginosis: 2001-2004 National Health and Nutrition Examination Survey data. Obset Gynecol. 2007; 109(1): 114-20.

2. Foxman B, Barlow R, D'Arcy H, Gillepsie B, Sobel JD. Candida vaginitis: self reported incidence and associated costs. Sex Transm Dis. 2000; 27: 230-5.

3. Ronnqvist D. Urogenital probiotics: potential role of Lactobacillus in the prevention of urogenital infections in women (dissertation). Umea University; 2007.

4. Parma M, Vanni VS, Bertini M, Candiani M. Probiotics in the prevention of recurrences of bacterial vaginosis. Altern Ther Health Med. 2014;20(1):52-7.

5. Mastromarino P, Vitali B, Mosca L. Bacterial vaginosis: a review on clinical trial with probiotics. New Microbiol. 2013; 36:229-38. 
6. Kumar N, Behera B, Sagiri SS, Pal K, Ray SS, Roy S. Bacterial vaginosis: etiology and modalities of treatment-a brief note. J Pharm Bioallied Sci. 2011; 3(4): 496-503.

7. Hillier S, Marrazzo J, Holmes KK. Bacterial vaginosis. Dalam: Holmes KK, Sparling PF, Stamm WE, Piot P, Wasserheit JN, Corey L, dkk, penyunting. Sexually transmited disease. Edisi ke-4. New York: McGraw-Hill; 2008. h. 737-68.

8. Centers for Disease Control and Prevention. Sexually transmitted diseases treatment guidelines. MMWR. 2010; 59: 56-63.

9. Mendling W, Brasch J. Guideline vulvovaginal candidosis (2010) of the German Society for Gynecology and Obstetrics, the working group for infections and infectimmunology in gynecology and obstetrics, the German Society of Dermatology, the Board of German Dermatologists and the German Speaking Mycological Society. Mycosis. 2012; 55(Suppl.3):1-13.

10. Liong MT. Safety of probiotics: translocation and infection. Nutr Rev. 2008; 66: 192-202.

11. Falagas ME, Betsi GI, Athanasiou S. Probiotics for prevention of recurrent vulvovaginal candidiasis: a review. J Antimicrob Chemother. 2006; 58: 266-72.

12. Anukam KC, Osazuwa E, Osemene GI, Ehigiagbe F, Bruce AW, Reid G. Clinical study comparing probiotic Lactobacillus GR-1 and RC-14 with metronidazole vaginal gel to treat symptomatic bacterial vaginosis. Microbes Infect. 2006; 8:2772-6.

13. Mastromarino $\mathrm{P}$, Macchia S, Meggiorini L, Trinchieri V, Mosca L, Perluigi M, et al. Effectiveness of Lactobacilluscontaining vaginal tablets in the treatment of symptomatic bacterial vaginosis. Clin Microbiol Infect 2009;15: 67-74.

14. Ya W, Reifer C, Miller LE. Efficacy of vaginal probiotic capsules for recurrent bacterial vaginosis: a double-blind, randomized, placebo-controlled study. Am J Obstet Gynecol. 2010; 203(2):120.e1-6.

15. Petricevic L, Witt A. The role of Lactobacillus casei rhamnosus Lcr35 in restoring the normal vaginal flora after antibiotic treatment of bacterial vaginosis. BJOG J Gy. 2008;115(11):1369-74.

16. Martinez RC, Franceschini SA, Patta MC, Quintana SM, Gomes BC, De Martinis EC, dkk. Improved cure of bacterial vaginosis with single dose of tinidazole $(2 \mathrm{~g})$, Lactobacillus rhamnosus GR-1, and Lactobacillus reuteri RC-14: a randomized, double-blind, placebo-controlled trial. Can J Microbiol. 2009;55(2):133-8.

17. Marcone V, Calzolari E, Bertini M. Effectiveness of vaginal administration of Lactobacillus rhamnosus following conventional metronidazole therapy: how to lower the rate of bacterial vaginosis recurrences. New Microbiol. 2008;31(3):429-33.

18. Marcone V, Rocca G, Lichtner M, Calzolari E. Long-term vaginal administration of Lactobacillus rhamnosus as a complementary approach to management of bacterial vaginosis. Int J Gynaecol Obstet. 2010; 110(3): 223-6.

19. Larsson PG, Stray-Pedersen B, Ryttig KR, Larsen S. Human lactobacilli as supplementation of clindamycin to patients with bacterial vaginosis reduce the recurrence rate; a 6-month, double blind, randomized, placebo-controlled study. BMC Womens Health. 2008; 8(3): 1-8.

20. Reid G, Bruce AW, Fraser N, Heinemann C, Owen J, Henning B. Oral probiotics can resolve urogenital infections. FEMS Immun Med Microbiol 2001; 30: 49-52.

21. Martinez RC, Franceschini SA, Patta MC, Quintana SM, Candido RC, dkk. Improved treatment of vulvovaginal candidiasis with fluconazole plus probiotic Lactobacillus rhamnosus GR-1 and Lactobacillus reuteri RC-14. Lett Appl Microbiol. 2009; 49: 269-74.

22. Kovachef SM, Vatcheva-Dobrevska RS. Local probiotic therapy for vaginal Candida albicans infections. Probiotics Antimicrob Proteins. 2015;7(1):38-44.

23. Murina F, Graziottin A, Vicariotto F, De Seta F. Can Lactobacillus fermentum LF10 and Lactobacillus acidophilus LA02 in a slow-release vaginal product be useful for prevention of recurrent vulvovaginal candidiasis?: a clinical study. J Clin Gastroenterol. 2014; 48: S102-5. 